\title{
Muslim Immigrant Students in European Higher Educational Institutions
}

\author{
Siranush Chubaryan \\ University of South Carolina, US
}

\begin{abstract}
This study investigates the influence of higher education on the integration of Muslim students from migrant background into French, German and Armenian societies. In 1999 many European states signed the Bologna Declaration (also Bologna Process), the goal of which was unification of European higher Education under one umbrella. In line with many aims stated in Bologna Declaration, one of the eye-catching characteristics was the policy's flexibility, which would allow students enrolled in higher education institutions all over Europe to voice and promote their social, educational, cultural needs and take part in decision-making processes.

To be able to understand whether the Bologna Process plays a role of integrator for Muslim immigrant students as well, the research attempts to reveal how Muslim immigrant students perceive and describe their experiences with European higher education; how they describe their integration into European institutional environment and consequently into European society. For this purpose case study approach has been applied. Individual interviews with student-participants have been conducted.
\end{abstract}

Key words: Muslim immigrant students; Europe; Bologna Process; higher education policy; integration .

\section{Introductory Remarks}

My interest in the experiences of Muslim students from migrant background in European higher educational institutions under the Bologna Process grew after I heard the stories told by student participants during an international civic education conference held in Armenia in 2008. In my professional life, I have traveled a lot and participated in many conferences in different European states, where I frequently heard different intriguing stories about Muslim students. The stories varied, as they were told by different people of several ethnic and 
religious backgrounds, but most of those stories had one detail in common: Muslim immigrant students are understood to be disengaged compared to other groups of immigrant students. Even the Bologna Process, with its flexibility, does not entirely solve the problem of "alienation and detachment" of Muslim students.

The stories that I have heard from these students show that even if they have spent their whole lives in Europe, Muslim students are often mistreated. One of the students brought to light several key issues related to immigration: religious identity, social identity, education, and integration. For the immigrant population, the issue of identity is quite complex, because immigrants often try to adapt and fit in to their new environment. In this process, their identities undergo changes. The notion of identity becomes especially contentious when it comes to the Muslim students of migrant background (especially after tragic events of September 11, 2001). Before September 11, 2001 the presence of Muslim immigrants in Europe's economic, political, cultural, educational spheres was not discussed nearly as much as it is now. While issues of integration have always been challenging for Muslims in Europe, the challenges have become particularly acute after 9/11. Moreover, often the attitudes, structures and existing policies of some European states (e.g. France, Germany, United Kingdom, Armenia, etc.) hinder Muslim immigrant students' educational, civic, and social integration, becoming obstacles for those students in building their future careers and lives while legally residing in Europe.

Although there is a vast literature (e.g. Barseghyan 2010; Markaroff 2011; Shadid 2002; Kamaroff 2010; Melnikov 2002; Landa 2004) around the topic of Muslim immigrants in Europe, the research still lacks depth on the ways in which Muslim students from migrant background perceive the problems they face while attending European higher educational institutions. The main focus of researchers (e.g. Markaroff 2011; Landa 2004; etc.) is general Muslim population, including their cultures, traditions, the practice of Islam in West. There is also research (e.g. Shadid 2002; Melnikov 2002, etc.), which focuses on Muslim second-generation immigrants' religious identity in one specific country context (e.g. Netherlands). Finally, it is important to take into account the solutions proposed by Muslim students themselves and consider their suggestions for enriching their academic and civic experiences.

The stories told by Muslim students inspired me to initiate this study in order to have a deeper understanding of the interplay between current educational 
policy (e.g. the Bologna Process) and the integration of Muslim students from migrant background into educational, civic, and social life of Europe. For this purpose the following questions are going to be addressed within the framework of the present paper:

1. While studying in a European higher educational institution, how do Muslim immigrant students describe their experiences with European education?

2. How do they describe their integration into European institutional environment and consequently into European society?

\section{The Countries Selected as Cases: Germany, France and Armenia}

The existing policies on religious and minority rights in France, Germany and Armenia seem to be quite strict, even relating to traditional Muslim female populations' use of headscarves in educational institutions. For instance, David Sapsted (2010) indicates that Germans' attitudes towards Muslims is noticeably more intolerant compared to people from other Western European countries. Another example is the French government's law that prohibits the presence of any kind of religious signs in schools and universities. According to Bouzar and Kada (2003), Muslims in France do not enjoy their religion as much as other residents of the country enjoy theirs. Finally, I would like to say that historically, Christian Armenia has always struggled in its relations with its Muslim neighbors (e.g. the Armenian Genocide by the Ottoman Empire, the ongoing conflict with Azerbaijan in the disputed Nagorno-Karabakh region, etc.). Jaloyan, while talking about Muslims in Armenia, outlines that, "We have always had problems with Muslims. Now what we have is increasing number of Persian population, which is trying to take over our country" (Jaloyan 2010:28).

While discussing the choice of these three countries, it is important to mention that all three countries are part of the same higher educational policy (i.e. The Bologna Process). Thus, according to François Orivel, "The origin of the Bologna process in France can be traced in a report prepared at the request of the Ministry of Education in 1998. This report was aimed at proposing a harmonization of the structure of diplomas in the European space," (Orivel 2005:2). After the signing of the Bologna Declaration and introducing the process into the French educational system, higher education in France was no longer state funded. The tuition fee is not currently very high (ranging from 150-700 Euros yearly for public institutions, 700-15000 Euros for private 
institutions), but it still could be a problem for immigrant population in general, making their access to higher education more difficult.

Germany was also among the 29 European countries to sign the Bologna Declaration in 1999. As Mause explains, "What is interesting is that the Bologna Declaration was not a legally binding contract amongst the states who signed it. There also existed no sanctions for the non-implementation of the Bologna objectives. The same holds for the subsequent declarations published within the ongoing Bologna Process," (Mause 2013:19). Thus, in Germany the change in the higher education system had more of a gradual character. Due to governmental pressures starting from the winter term of 2010, German higher educational institutions introduced Bachelor's and Master's degrees into higher educational institutions all over Germany, making the system more in tune with the Bologna Process. Higher education in Germany, though, is still state funded, which means that high tuition cost is not a potential hindrance to Muslim immigrant students' education process.

After Armenia signed the Bologna Declaration in 2005, reforms have taken place in the Armenian educational system, which aim to restructure it into an integrated educational system and to provide multifaceted education. According to Bekaryan, "The integrated educational system would also give a priority to basic scholarly research activities and will integrate the primary goals of the university to create exchange and import knowledge," (Bekaryan 2010:27). The achievement of these goals was possible through the introduction of a flexible three-degree system including Bachelor's, Master's, and Doctoral degrees, as well as through the introduction of new content into curricula. Along with positive effects, there were very negative outcomes, which I should outline. The education that was once completely free is now quite expensive, especially for a country like Armenia. This means that many potential young students, including Muslim immigrant students, are not able to have equal access to education. Armenian educational institutions, in contrast with other Western/European states, do not really employ the scholarship system, which would allow lowerincome students to have equal access to education.

The introduction of tuition fees could be one of the potential challenges within the framework of the Bologna Process, which could hinder the equal access of Muslim immigrant students to education in Armenia and France. For instance in Armenia the scholarship system for students in general is not wellestablished, which makes it hard for students apply for grants and financial 
assistance. In France the education is not state funded, but it is more or less affordable. Since the education in Germany is state funded and Muslim immigrant students still face problems while studying in higher education institutions in Germany, tuition fee appears not to be one of the main challenges within the Bologna Process in the country. It is important to mention, though, that there are many foundations all over the world (e.g. A.Q.M Salehuddin and Najmun Nisa Memorial Trust, Aamir Mustafa Kidwai Trust, etc.), which financially assist Muslim students all over the world, making their access to education easier.

\section{Literature on Education's Role in Muslim Immigrants' Life}

Many research works find education to be the main means of integration for Muslim immigrants into European society. Research that focuses on the interplay of education and integration of Muslim immigrants mostly draws upon factors like academic attainment of Muslim immigrant students, dropout rates, introduction of new classes into schools, which could either hinder or promote the integration of Muslims (Gesemann 2005). There are also studies which focus on the identity of Muslim immigrants (mostly religious) within the framework of general education. Also, research gives consideration to Muslim female students, while discussing the role of Education (Jackson 2008).

Gesemann discusses information regarding the immigrant students' academic progress, based on the new the Programme for International Student Assesment (PISA), and IGLU (International Primary School Reading Study) comparative studies. Gesemann states:

The results of the PISA comparative study conducted by the OECD show that the differences in reading competence among youths from upper and lower social classes is greater in Germany than in any other country participating in the study. Affected here in particular are children of the working class and of immigrants. Pupils 15 years of age, both of whose parents were born in Germany, have chances of attending Realschule or Gymnasium which are two to three times as good as pupils of the same age who come from pure immigrant families (Gesemann 2005:10). The research suggests that there should be supplementary education designed for immigrants and children of working-class families to promote the entire integration process.

Many researchers see integration of young Muslim immigrants through the introduction of religious education into general education. In this regard, 
Jackson (2008) outlines that European inter-governmental institutions emphasize and advocate the study of religion in public schools all over Europe. OSCE has developed recommendations regarding the integration of religious study into the school curriculum. While trying to integrate religious studies into public education, European governments realize that appropriate pedagogical approach should be developed, which should be engaging for all students and will address the importance of religious identity. Jackson (2009) mentions that through integration of religious studies, Europe hopes to engage immigrants in European civics.

When it comes to higher education, the whole picture regarding the integration of Muslim immigrant students gets even more confusing. Higher educational institutions are considered to be spaces where students can interact and engage in different issues related to academic and social life. Immigrant students studying at universities are not exceptions (Scott 1997). Asmar (2006) and Gilliat-Ray (2000) assert that some needs of Muslim students have to be met to make their integration process into European society smoother and easier. The list of those needs is mostly related to religious rituals (e.g., praying, available prayer space, Halal food consumption, etc). Modood (2005) criticizes the approach of the European education system towards the Muslim immigrant population, stating that the practiced approach does not respect multiculturalism. Modood asserts that European universities do not really satisfy the basic needs of Muslim immigrant students, thus hindering the students' social integration. According to Modood (2005) there should be an intercultural dialogue to promote Muslims' social engagement. Ortuno (2009), in line with Modood (2005), emphasizes the absence of dialogue between locals and immigrants.

Another major aspect hindering the integration of Muslims is the overall discrimination against them. The increase in discrimination is especially noticeable after the 9/11 terrorist attacks. Appleton (2005) points out that according to Muslim immigrant students, the attitude of Europeans towards them sharply shifted towards the negative after 9/11. Muslim students experienced not only verbal but also physical attacks by local Europeans. Appleton indicates that those attacks make Muslim students feel apathetical towards their studies, as well as integration into European society in general. Regarding the negative attitude towards Muslim students, Tyrer and Ahmad (2006) notice the presence of Islamophobia on the campuses of universities. The 
negative attitude is especially obvious towards Muslim female students, who usually wear their traditional dresses and cover their heads.

Though 12 years have passed after the tragic events of 9/11, the situation for Muslim students in Europe has not improved. Jaloyan, after interviewing 20 Muslim immigrant students studying in higher educational institutions, explains that Muslim students experience hardships. These hardships are not because they do not study hard or have issues related to French, but because of their religious background. Jaloyan's study and his interviews with those 20 students show that European professors have negative attitudes towards Muslims, and especially towards Muslim females, because, as Jaloyan mentions, "It is easier to identify the female's religious belonging sometimes, than that of males," (Jaloyan 2008:37).

Another eye-catching study regarding Muslims' integration is Kalinin's research in 2010. Through interviewing 10 European students from France, UK, and Spain, the researcher tries to understand their perception of their Muslim peers. The study reveals that the attitudes of Europeans towards their Muslim immigrants differ. Some students outlined that they have Muslim friends. Others indicated that Muslims present a potential danger for the future of Europe. There are also students that singled out the role of media in shaping negative attitudes towards Muslim population in general. Kalinin suggests that development of special programs at higher educational institutions where locals and immigrants can get together and tell their stories to each other could help to solve the issue of negative attitudes. The study concludes that those integrative programs could be the beginning of mutual understanding, which could help both parties. To summarize his research results, Kalinin mentions that in this respect policy makers could try to make educational policies more flexible, stating, "Course credits...they may be important. But they lose importance, when not every student is engaged. This means that there is a problem, which policy makers could try to fix," (Kalinin 2010:76).

Mitchell, while discussing neoliberal governmentality and its influence on European education asserts that both the policies and the programs associated with education and training are becoming more oriented towards the formation of mobile, flexible, and self-governing European laborers and less oriented towards an institutionalized affirmation of personal development and individual or group 'difference' (Mitchell 2004:3). 
Mitchell thinks that the flexibility of the European educational system should make the integration of immigrants in general easier. But is this also true for Muslim immigrants? How do Muslim immigrants see the role of education in promoting their own integration?

\section{Limitations of the Study}

My research is a set of individual case studies that I compare. The main method of my data collection consists of semi-structured interviews with nine Muslim immigrant students from France, Germany and Armenia. The study is not therefore statistically representational and cannot be generalized. Because the study is of international character, I could not be present in the countries for long periods of time, limiting my contact with the student-participants.

\section{Methods}

Qualitative Research. I think that in general most of the inquiry methods used by researchers can make substantial contributions to research and provide profound knowledge about the examined topics. Since my research mostly carries international and comparative components, and because I focus on notions like the interplay of educational policy and integration as human experiences, I thought that it would be appropriate for me to use qualitative methods of inquiry. By using qualitative methods I was able to conduct a more profound examination; I was able to focus, understand, explain, and interpret the collected empirical data. My research is more individualized with data collected through individual conversations with the participants of my research.

Case Study Approach. While thinking about the research approach I would be using in my examination, I went through a lot of articles and books (Maxwell, 2004; Maxwell, 2005; Yin, 1984, etc.) that offered a variety of methods to be applied in research in general. I thought about the goals of my research and came to the conclusion that what I am doing in my examination is looking at particular groups of participants and their experiences in a specific context (e.g., European context). At the same time, it is important to provide detailed information about the researched phenomenon through individual stories. Since I was conducting research on Muslim immigrant students in one specific context (e.g., European context), it meant that I was not going to look for or focus on a universal truth. Instead, what I, as the researcher, would do was mostly related to examination and description of what was happening. 
According to Yin, it is an empirical inquiry which enables researchers to investigate "contemporary phenomenon in a real-life context," (Yin1984:23). Further, he outlines that there are "no clearly defined boundaries between phenomenon and the context" and in this respect he recommends the use of multiple sources of evidence. Taking into account the importance of the interrelationship between phenomenon and the context, I think that the case study approach was the most appropriate for my research, as I would be examining Muslim immigrant students in European context.

\section{Data on Muslim Student-Participants}

I used two main sources to gather data for my research: personal interviews with student-participants, their written reflections. The discussion of each method follows.

Interviews. Interviewing in general is a quite informative process. The data collected makes it possible to become more enlightened and learn more about the issues the research is focused on. Glesne (1992) describes interviews as an "alternative" source of finding answers to questions of interest. Inspired by this definition, I was able to gather important data by interviewing studentparticipants on their experiences as Muslim immigrant students. Research in the field of phenomenology suggests that interviews should consist of three interview series: Focused life experiences; the details of experience; and reflection on the meaning (Mills 2010; Seidman 1998; Smagorinsky 2008).

Reflections Written by Muslim Student-Participants. I chose written reflections as another source of data because I think that written reflections can provide more comprehensive data and make the entire data collection process more informative. In this regard, I would like to mention that I based my choice of written reflections on my personal experience. While working as a research assistant at the Office of Program Evaluation the University of South Carolina, I conducted many focus groups, as well as individual interviews after which the interview participants were requested to write reflections around the questions asked during the interview. To my great surprise, those written reflections were more detailed and uncovered some issues which were not voiced during the interviews. Hubbard and Power (1999) and Mills (2003), while discussing qualitative research methodology and its practical use, emphasize that data from written reflections together with interviews "draw patterns and categories from responses." Those responses can be especially useful for data analysis. 
After coding the data, I started building as well as analyzing each individual case. Cross case analysis followed the single case analysis.

\section{Analysis and Results}

I conducted my research interviews in the following universities: Yerevan State University (Armenia); Frankfurt Am Main University (Germany); Science Po University, Menton (France). To my surprise, there were many immigrant students with a Muslim background who expressed a willingness to participate in interviews. I conducted a group interview first in order to determine which students had really interesting stories to share with me. After discussing general questions related to my research, I chose three students from each university: The students represented the following countries: Algeria, Yemen, Lebanon, Turkey, Morocco, Iran, India, Uzbekistan and Egypt. While making my choice among the volunteers, I based my decisions on bringing into my project as much diversity as possible (e.g. diverse nationalities, age as well as gender). I conducted three rounds of interviews with each and every student. The interviews were individual.

The interviews were individual. Names of student-participants are the following: Viola, Ahmed, Sasan (Armenia); Erdi, Mayana, Said (Germany); Amal, Khaled, Jhoka (France).

According to the students interviewed, there were various obstacles they needed to overcome in order to feel accepted by locals. Shahnazaryan (2011) asserts that institutions of higher education possess the ability to make the integration of immigrant students easier and less painful.

In this section I focus on analyzing the results of the data on experiences of Muslim immigrant students in their respective institutions of higher education. I try to answer whether or not Muslim immigrant students feel integrated into their educational environment in particular and into French, Armenian and German society in general based on the data of interviews with the students.

Next, I discuss what the students indicated as the existing problems and obstacles that hinder their integration into their educational environment as well as European society. I look at participants' experiences with their peers as well as professors, and I try to determine to what degree they felt accepted by the locals. To make the points discussed clearer, I refer to notions like: religion and ethnicity, language, unequal treatment, and the feeling of being an outsider. 
Finally, I also talk about the suggestions the participants made regarding possible ways of making their integration easier and smoother in their new homelands.

\section{Higher Education and Integration:}

\section{How Immigrant Students See Their Integration}

Shabayev (2009) finds it very important for immigrants from Muslim backgrounds to enroll in institutions of higher-education in their host countries, asserting that higher education can have a positive influence on immigrants' integration in general. While Shabayev (2009) has very positive feelings about higher education's role as an integrator, Polich (2011) states that European institutions of higher education all over Europe may discourage many Muslim immigrant students from continuing their educations, explaining that sometimes a very tense atmosphere exists inside the institutions and there are prejudices toward Muslim immigrant students. At the same time, Ghukasyan (2008) indicates that many Muslim students do not want to integrate and that higher education cannot play any role in their integration, even if they are part of that institution. As opposed to Ghukasyan, Wright (2012) states that immigrants do not integrate because: "They feel and see the silent conversation among locals and themselves" (Wright 2012:56). He asserts that any immigrant is willing to integrate and to support the entire integration process; immigrants should be approached individually. Comparing immigrant students with first grade elementary school students, Wright points out that they are even more vulnerable than first grade students and require individual approach (Ibid).

When I look at the data provided by the students, I notice an interesting tendency across all nine cases. Although students came up with different thoughts and ideas on integration, there is at least one commonality among all nine cases: "Being integrated means being accepted." The data shows that the perception of the three students studying in Armenia (Viola, Ahmed and Sasan) of their higher educational institution (Yerevan State University) varies. Viola found it really complicated to become part of her institutional environment because she had a hard time communication with her Armenian peers, while Ahmed and Sasan were doing their best to make Armenian friends because they thought it would help them better integrate into their educational environment in particular and Armenian society in general. But all three students indicated that one of the most important aspects of integration is acceptance by Armenian 
society. In addition to "being accepted," Ahmed found himself in the middle of a "cultural game," stating that his integration also depended on accepting the local cultural value system.

The same tendency is noticeable among students studying in Germany and France. Despite the fact that some of the students were successful in their communication with local peers, they still felt that they were not accepted by many people within their higher educational institution as well as outside of it. An interesting fact that I notice in the student data is that Khaled and Amal (students studying in France) did not pay attention to the bad attitude toward them coming from local Europeans because they realized that, if they wanted to be accepted and integrated, then they needed to ignore those "negative messages" and just do their work and try to maintain their friendship with their European friends. I am inclined to believe that it is due to their childhood in the multicultural countries of Algeria and Morocco and the influence of their families that Amal and Khaled were able to ignore the existing bad attitude and willingly continue their integration process into the society of their new homeland.

Another tendency that I notice among all nine cases is that students try to "look like Europeans." The data shows that all 9 students, for example, mostly spoke the local language even if they interact with people who knew their mother tongue. Another important thing is that students try to wear clothing that will make them look like their local peers. A good example is Sasan's case. $\mathrm{He}$ indicated that he did not want to look like other Persian students who wore specific colorful clothing and had different haircuts. Sasan tried to look like Armenian students.

Yet another commonality among all nine students is that they find their integration into their own higher-education environments important because they think that it will facilitate not only their entire educational process, but also their integration into European society in general. Even though, for instance, Amal and Khaled saw quite a progress in their integration, all 9 students still came across various obstacles that could potentially hinder their integration. In the section to come, I try to reveal those obstacles based on the data provided by students.

\section{Obstacles Hindering Integration}

Religion and Ethnicity. The stories of interviewed students tell us that often they avoid questions related to their ethnicity, nationality, and religion. 
While looking at the data of the 9 student participants of my study, I can see that the abovementioned results hold true for them as well. Viola realized that her ethnic background and her religion could potentially hinder her integration into Armenian society and stopped wearing the hijab, despite the fact that Armenian institutions of higher education do not prohibit it. Viola also pointed out that local students would often tease her for the clothing she wore, which made her make some changes in her appearance. But Viola could not hide her ethnicity and, according to her, everyone in her institution knew that she was from Uzbekistan. In contrast to Viola, Ahmed did not plan to make major changes to hide his nationality or religion. He thought that studying hard and being a good student could help him overcome problems related to his integration and make locals believe that "being an immigrant from Muslim background is not a mental disability." In contrast with Viola and Ahmed, Sasan almost never interacted with other Iranians, and he tried to wear clothing in the style of Armenian students. He did not consider himself a Muslim, and when asked questions about his nationality he presented himself as Armenian, and the most astonishing thing is that he sometimes wore a cross around his neck. Like Sasan, Erdi, finding himself in the middle of integration problems, thought that giving up his religion, presenting himself to others as German, and wearing European-like clothing could make his integration into German society smoother. Erdi thought that the changes he had undertaken seemed to have made his integration easier.

Mayana (student from Germany) tried to avoid religious practices and think and act more like Europeans, but at the same time she indicated that she did not feel accepted either by Europeans or by immigrant students from a Muslim background.

I understand why covered Muslims don't accept me. It is because they know that I should be Muslim, but in reality I am not. I don't even wear their type of clothing. But I feel like there are many European students who just don't want to interact with me.

Mayana, like Viola, still felt badly integrated, despite the self-changes she had been through.

In contrast with other students, Said was one of those lucky students whose appearance was more or less European, which helped him avoid questions related to his nationality and religion. Said, similar to Sasan, did not wear Muslim-specific clothing, and he tried to act and think like European: "I try to 
behave like Europeans; I wear the same type of clothing; I eat the same type of food; and I listen to European music only."

Jhoka's case was very similar to Viola's case: lack of friends and interaction, lack of acceptance, and low levels of communication. Despite the fact that Jhoka did not use her Yemeni clothing inside institutions, she did not feel that it helped her to integrate. She realized that her religion and ethnicity, especially after recent tragic events in France, could hinder her integration into French society, but she did not feel like giving up either her ethnic identity or religion. She thought that if people were going to accept her, they needed to accept her the way she was. In contrast with Jhoka, Khaled did not seem to have major problems in adapting to his institutional environment. But at the same time, Khaled, like Erdi, tried to act French and think French, because he thought that that type of behavior could influence his integration positively. Khaled said that he did not really like concepts such as nationality and religion. I think that such an attitude toward those concepts is due to the fact that Khaled realized that nationality and religion were potential obstacles toward his integration. Amal's case is similar to Kahled's case in sense that Amal did not seem to have major problems related to her ethnicity or religion. Amal herself did not outline the fact that she was Muslim, but she stated that she just had belief in God. Also, Amal mentioned that Morocco's being a multi-national country made it easy for her to be accepted by French society without having problems related to her ethnic background. At the same time, she realized that Muslim immigrants from other countries do have issues related to ethnicity and religion. Like Mayana, Amal mentioned that sometimes she felt non-accepted by other Muslim students due to her free outlook and communicative behavior.

Language. Transition to new culture and environment can be very stressful. An important part of a new culture for an immigrant is the official language of the country. Nelson (2008) asserts that integration into a new society is much easier if immigrants learn the language of their new homeland. Nelson (2008) also states that the tendency to learn the local language is especially noticeable among the younger generation of immigrants and, more specifically, among those youngsters who want to be well educated in order to be able to build their future in the new country.

My interviews with all 9 Muslim immigrant students suggests that they realized the importance of knowing and speaking the language of their host country. My observations show that, for example Viola, did realize the 
importance of learning and speaking Armenian. She could also understand that speaking the local language would potentially improve her integration into Armenian society. Viola did not have an easy time learning Armenian. As to Ahmed and Sasan, both of them realized that knowledge of the Armenian language could play an important role in their integration. Both of them learned Armenian before entering Yerevan State University to be able to enroll in mainstream classes with Armenian students. Most of the time they speak Armenian. Sasan's story reveals that he avoided communication with other Iranian students and tried to speak only Armenian. Ahmed also indicated that he preferred to speak Armenian most of the time. Moreover, Ahmed's major was Armenian history, not only because he was interested in it, but also because he thought that knowing the history of his host country better, would make his integration smoother. Similarly, Mayana, Erdi and Said found the knowledge of German important and thought that it could definitely make their interaction with Germans easier. Moreover, they often tried to speak German because, according to them, by doing so, they avoided questions related to their ethnic as well as religious background. While Amal and Khaled had no problem speaking French, because they grew up speaking French, Jhoka attended specialized courses in French for foreign students who were planning to continue higher education at Science Po. In contrast with Amal and Khaled, Jhoka's parents did not speak any French and they did not encourage their children to speak French. But Jhoka, realizing the importance of speaking the local language as well as its positive influence on integration, did learn French and tried to speak it most of the time.

Unequal treatment and the feeling of being an outsider. All 9 of the student-participants in my study considered unequal treatment, which makes students feel like outsiders, to be one of the major issues they dealt with. Thus, despite the fact that Amal and Khaled were more or less integrated into their educational environment, they also felt unequally treated by their professors and thought that such treatment could be detrimental to the integration of Muslim immigrants. Amal did not talk much about unequal treatment toward herself, but her data makes it clear that she was aware of an existing problem and noticed that many Muslim immigrant students did face that problem. Khaled did talk about his own unequal treatment and existing prejudices toward him. At the same time, both Amal and Khaled preferred to ignore the negative treatment, considering their integration vitally important for their education in particular 
and life in France in general. They kept up with making many friends among the French and other Europeans, and they were actively involved in educational activities. Both students perceived that their integration was vitally important and preferred not feel like outsiders.

Jhoka's, Viola's, and Mayan's cases shows that the three young students did have hard time integrating into both their educational environment and into the societies of their host countries. The data of these three students reveals that professors did not treat them well. The students could not make friends with local students, which would make their integration smoother. They felt like outsiders and distanced from Europeans. The students thought that unequal treatment by their professors reflected on the students as well and caused the local population to keep away from them. This type of attitude made all three students feel "othered" inside and outside of their institution. According to the data, very few professors were supportive and approachable.

When I compare the Erdi's, Said's, Sasan's, and Ahmed's cases, I notice that all four felt unequally treated by professors and even sometimes by students. The data also reveals that all four students had good knowledge of the language of their host country and mostly interacted with locals both inside and outside the institution. They thought that interaction and communication with local European students was the main key to their integration. And all four students did their best and studied hard to prove to their professors that they deserved better treatment.

To conclude, I would like to add that all nine students knew that their integration was important not only for their education but also for their attempt to become good citizens of their host countries.

All nine cases demonstrate that professors' unequal treatment influences the opinions of local students about Muslim immigrants. At the same time, Muslim immigrant students think that the reason behind their unequal treatment is their religion and the country of origin. That is the main reason students avoid speaking their native language, try to behave like Europeans (for example, through clothing, thinking, and so on), and even sometimes ignore negative messages from their professors and peers.

\section{Conclusion}

As we saw from the above discussion, all nine students discussed various obstacles related to their integration. Students also highlighted that integration 
was vitally important for them, not only for their successful completion of their education but also for becoming lawful members of the society of their respective host country.

Gyurzaev, while looking at various institutions of higher education all over Europe, talks about diverse population of migrant students from different ethnic as well as religious backgrounds. The researcher observes different groups of students, examines issues related to their integration, and asserts that there is a tendency among students from Muslim backgrounds not to integrate as well as migrant students from Christian backgrounds. He indicates that Muslim students feel segregated because they often feel they are mistreated by their professors and peers. The researcher also discusses the student cliques and notes that often students from Muslim backgrounds tend to interact among one another and try to keep a distance from their European peers. At the same time, he makes us aware that the overall educational environment does not really play a role of integrator the way it should. One of the main solutions suggested by the researcher is the incorporation of culture-related subjects and activities in which all students can participate, present their culture, and talk about their problems both inside and outside their institution. This would enable local European professors and peers know immigrant students better (Gyurzaev 2011).

Al-Mahmud conducts a similar study where he looks at various educational institutions in France. The researcher states that, while the student population is diverse, the professors' population consists of mostly local professors. $\mathrm{He}$ stresses the importance of recruiting and hiring professors from migrant backgrounds, which would bring the overall institutional population into some kind of balance. The researcher thinks that having migrant colleague would help local professors better understand the hardships that migrants face and treat students equally (Al-Mahmud 2013).

Thus, considering the experiences of the 9 student-participants of my study, I have suggestions that are consonant with those suggested by Al-Mahmud and Gyurzaev. The student participants think that their integration into their educational environment and, consequently, into French society would be smoother if the educational institutions offered recreational facilities for all students, so that they could attend those and get to know one another. Diverse cultural and interactive student clubs are among the means students thought 
could support their integration. By attending those clubs, students from various backgrounds could interact and share their interest.

Student participants also discussed the curriculum. Mayana suggested the following: "The university curriculum should incorporate subjects related to immigrants, to their issues, problems, and hardships. That way European peers will know more about our lives, and it is very possible that their treatment will change toward better." Among other suggestions related to changes in curriculum was the suggestion to include subjects related to culture, which could help European students know more about the countries where their immigrant peers came from. Jhoka said, "I think there should be some informative classes for locals, where they can learn more about Islam and Muslim immigrants and understand that not all of us are scary."

Finally, students stated that they lacked one-to-one meetings with their professors where they could talk about education-related problems and find solutions together, mentioning that those meetings would be helpful for both students and professors. Professors would thus get to know migrant students better, which could be beneficial for their integration. Also, student-participants mentioned that most of their professors were local Europeans and saw a need of having professors who had migrant backgrounds:

Another important thing would be to hire a diverse group of professors, which would be helpful. I know many educated people from Muslim background who used to be professors in their countries and who are really proficient in the field of political science. Why don't they hire those people when the institution lacks professors of certain subject fields? If the local professors interacted with migrant professors, they would probably change their negative attitude.

In sum, the discussion above shows that the 9 students had various experiences while studying at their respective institutions of higher education. Some students continued to face many difficulties while trying to integrate into their educational environment and into the society of their host country. All students thought that integration was vitally important for them because problems with integration would exert a negative influence on their education, their future careers, and their lives in Europe. The students talked about the potential obstacles that they thought could hinder their integration. Finally, the students made suggestions and came up with different ideas for making their integration in their educational environment smoother. 


\section{References:}

1. Asmar, C. (2006) Inclusive Practice in Relation to Students of Diverse Religious Backgrounds, with Special Reference to Muslim Students. Sydney: University of Sydney.

2. Appleton, M. (2005a) The Political Attitudes of Muslims Studying at British Universities in the Post-9/11 World. Part 1. // Journal of Muslim Minority Affairs, 25 (2), pp. 171-191.

3. Al-Mahmoud, M. (2013) La Influencia de la Educacion en los Estudiantes. / Doctoral dissertation. Universidad de Granada.

4. Barseghyan, A. (2010) Where is Armenian Education Heading? Yerevan: YSU Press.

5. Bouzar, D. \& Kada, S. (2003) L'une Voilée, L'autre Pas. Paris: Albin Michel Press.

6. Bekaryan, K. (2010) European Integration and Armenian Education. Yerevan: YSU Press, pp. 244-47.

7. Gesemann, F. (2005) The Integration of Young Male Muslims in Germany. Education and Training as Key Areas for Social Integration. London: Friedrich-Ebert-Stiftung. / Electronic ed: Bonn: FES Library. Available at: $<$ http://library.fes.de/pdf-files/bueros/london/03683.pdf $>$ [Accessed April 2016].

8. Gilliat-Ray, S. (2000). Religion in Higher Education: The Politics of the Multi-Faith Campus. Aldershot: Ashgate.

9. Glesne, C. \& Peshkin, A. (1992) Becoming Qualitative Researchers: An Introduction (p. 6). White Plains, NY: Longman.

10. Ghukasyan, G. (2008) Resisting Minorities. Yerevan: YSU Press, pp. 135155.

11. Hubbard, R.S. \& Power, B.M. (1999) Living the Questions: A guide for teacher-researchers. York, ME: Stenhouse.

12. Jackson, R. (2008) Teaching about Religions in the Public Sphere: European Policy Initiatives and the Interpretive Approach. // Numen, 55 (23), pp. 2-3.

13. Mause, K. (2013) With Bologna in Mind and the Sword in the Hand: The German Bachelor/Master Reform Reconsidered. // Higher education policy journal, 19(1). Available at: <http://www.palgrave-journals.com/hep/ journal/vaop/ncurrent/abs/hep20134a.html> [Accessed April 2016]. 
14. Maxwell, J.A. (2004) Qualitative Research Design: An Interactive Approach. Thousand Oaks: Sage Publications, Inc.

15. Maxwell, J.A. (2005) Qualitative Research Design. $2^{\text {nd }}$ edition. Thousand Oaks, CA: Sage Publications.

16. Mills, G.E. (2003) Action Research: a guide for the teacher researcher. $2^{\text {nd }}$ edition. Columbus, OH: Merrill Prentice Hall.

17. Mills, G.E. (2010) Action Research: a Guide for the Teacher Researcher. $4^{\text {th }}$ Edition. Upper Saddle River, NJ: Merrill /Prentice Hall.

18. Mitchell, K. (2004) Crossing the Neoliberal Line: Pacific Rim Migration and the Metropolis. Philadelphia: Temple University Press.

19. Modood, T. (2005a) Multicultural Politics: Racism, Ethnicity and Muslims in Britain. Minneapolis: University of Minnesota Press.

20. Nelson, L.; Hiemstra, N. (2008) Latino Immigrants and the Renegotiation of Place and Belonging in Small Town America. Social \& Cultural Geography. Vol. 9 (3), pp. 319-342.

21. Orivel, F. (2005) The Bologna Process in France: Origin, Objectives and Implementation. ECONPAPAERS. Available at: <http://halshs.archivesouvertes.fr/docs/00/08/67/96/PDF/05010.pdf $>$ [Accessed April 2016].

22. Ortuño, E. (2009) La Educación de Los Musulmanes en Europa. Granda, La Universidad de Granada.

23. Sapsted, D. (2010, December 10) Germans Far More Hostile to Muslims than other Western Europeans. The National. Available at: $<$ http://www.thenational.ae/news/world/europe/germans-more-hostile-tomuslims-than-other-western-europeans $>$ [Accessed March 2016].

24. Scott, P. (2002) Reflections on the Reform of Higher Education in Central and Eastern Europe. Higher Education in Europe, N 27 (1-2), pp. 137-152.

25. Seidman, I. (1998) Interviewing as Qualitative Research: a Guide for Researchers in Education and the Social Sciences. $2^{\text {nd }}$ Edition. New York: Teachers College Record.

26. Shadid, A. (2002) Legacy of the Prophet: Despots, Democrats, and the New Politics of Islam. Kindle edition.

28. Shahnazaryan, G. (2011) Integration and Minority Cultures. Yerevan: YSU Press, pp. 260-80.

29. Smagorinsky, P. (2008) The Method Section as Conceptual Epicenter in Constructing Social Science Research Reports. // Written Communication, N 25 (5), pp. 389-411. 
30. Tyrer, D. \& Ahmad, F. (2006) Muslim Women and Higher Education: Identities, Experiences and Prospects. Liverpool: Liverpool John Moores University and European Social Fund.

31. Wright, M. and Bloemraad, I. (2012) Is there a Trade-off between Multiculturalism and Socio-Political Integration? Policy Regimes and Immigrant Incorporation in Comparative Perspective. // Perspectives on Politics 10, N 1, pp. 77-95.

32. Yin, R.K. (1984) Case Study Research: Design and Methods. Beverly Hills, CA: Sage Publications.

33. Zaloyan, V. (2008) Azgayin poqramasnutyunner. Yerevan: Bamber.

34. Gyurzaev, V. (2011) Rol' obrazovaniya v Yevrope. M.: Pressa MGU.

35. Kalinin, P. (2010) Bolonskiy protses i musulmane $v$ Yevrope. // Pedogogicheskiy journal. N 8 (5), pp. 7-15.

36. Kamarov, I.P. (2010) Islam i zapad. // Journal po politologii. N 8 (1), pp. 3-14.

37. Landa, P.G. (2004) Musulmane na zapade. M.: Institut izucheniya Izrailya i blijhnego vostoka. Akademiya yestestvennykh nauk Rossiyskoy federatsii.

38. Melnikov, A. (2002) Musulmane v Yevrope. // Moskovskiy gosudarstvenniy universitet. N 235 (8), pp. 33-48.

39. Margelov, V. (2006) Vremya terrora i dilemmy resheniy. // Mezhdunarodnaya zhizn'. N 1 (2), pp. 29-38.

40. Malakhov, M. (2009) Religiya i intergratsiya. // Moskovskiy institut politologii. N 35 (9), pp. 34-67.

41. Polich, Sh. (2011) Novaya Yevropa, novye otnosheniya. M.: Pressa MGU.

42. Shabayev, G. (2009) Politika obrazovaniya v Yevrope. M.: Pressa MGU.

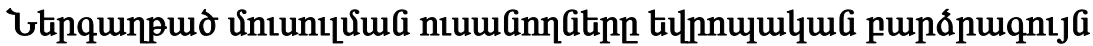 nıunıúauluma huuunuunnıpjnıGGitinnư}

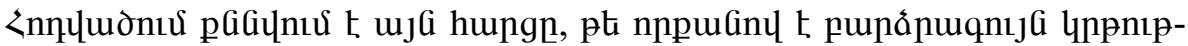

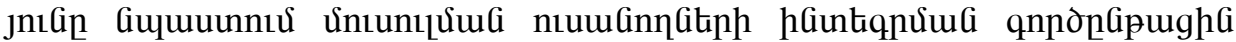

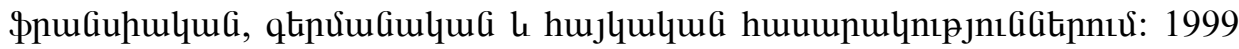

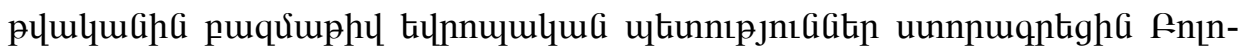

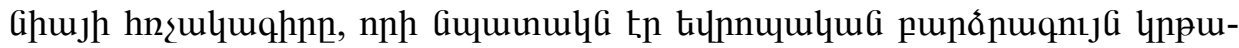

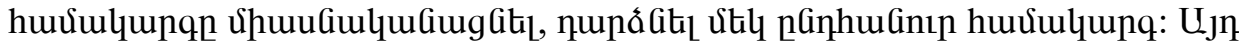

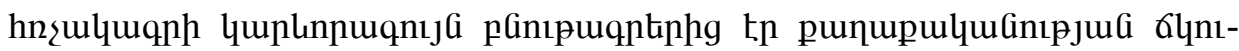

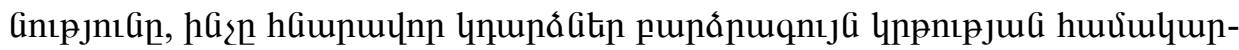




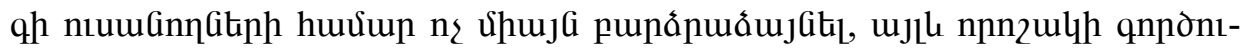

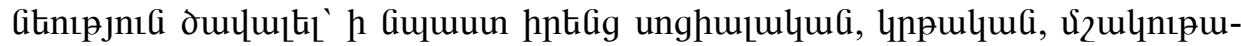

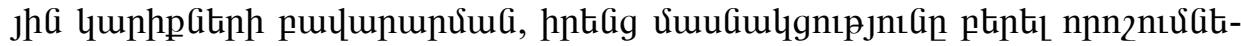

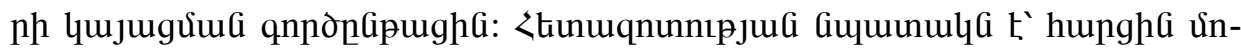

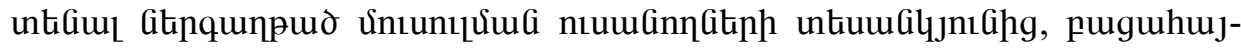

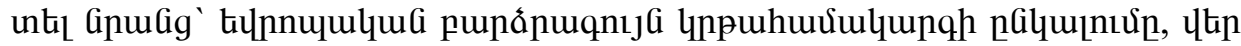

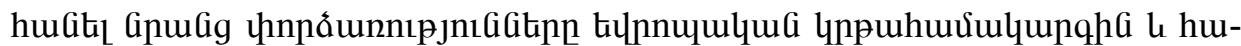

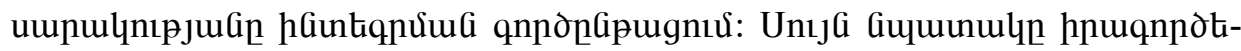

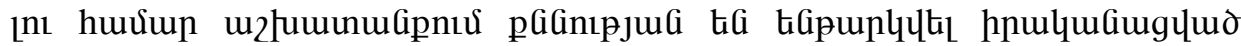

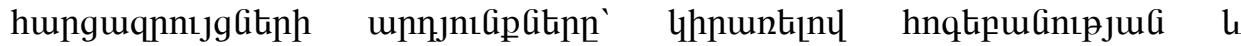

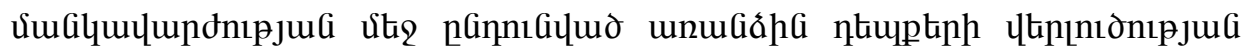
utipnnn: 